\title{
Jon Kvist
}

\section{Idealtyper og fuzzy mængdelære i komparative studier - nordisk familiepolitik i 1990'erne som eksempel ${ }^{1}$}

Fuzzy mængdelære er en ny metode i samfundsvidenskaberne, der giver mulighed for præcis operationalisering af teoretiske begreber, konfigurationer af begreber $i$ analytiske konstruktioner såsom idealtyper, og kategorisering af cases i relation til sådanne begreber og analytiske konstruktioner. Metoden er særligt velegnet til komparativ forskning og studier af diversitet, det vil sige forskelle og ligheder, mellem et medium antal cases. Artiklen redegør for hovedelementer i fuzzy mængdelære, og demonstrerer $i$ en analyse af de nordiske landes familiepolitiske udvikling i 1990'erne i relation til den idealtypiske socialdemokratiske familiepolitiske model, fuzzy mængdelæres brug i tid-rum sammenligninger og dens fordele sammenholdt med konventionelle case- og variabel-orienterede tilgange. 
K

omparative studier har været $\mathrm{i}$ hjertet af samfundsvidenskaheim, Smith og Tocqueville². Interessen for komparative studier har fået fornyet opmærksomhed de senere år i takt med opfattelsen af en stigende grad af socialt, politisk og økonomisk afhængighed mellem lande. Forskere og politiske aktører søger ihærdigt at forstå baggrunden for deres nationale institutioner, hvordan disse institutioner adskiller sig fra andre landes, samt hvilke effekter de kan tænkes at have. Teori, metode og sammenlignelige data er afgørende for værdien af sådanne studier. I denne artikel ser vi nærmere på de ofte 'oversete metodiske aspekter' (Hantrais og Mangen 1996). Et blik på nyere forskning inden for komparativ metode viser, at den traditionelle opdeling i kvalitative case-orienterede og kvantitative variabel-orien- terede metoder også afspejles i komparativ forskning (se fx Dogan og Kazangil 1994, Janoski og Hicks 1994, King et al. 1994, Hantrais og Mangen 1996, Goldthorpe 1997, Ragin 1997). Case-orienterede studier udvælger typisk et fătal af cases, som bliver behandlet i detaljen med omtanke for case-specifikke træk, hvorimod variabel-orienterede studier typisk ser på færre detaljer, men på en noget større gruppe af lande for at muliggøre statistisk databehandling. Figur 1 nedenfor viser dilemmaet, som de fleste komparativister står overfor, nemlig et trade-off mellem antal cases og antal aspekter, der inddrages. Enten kan man vælge at studere kompleksiteten $i$ et mindre antal cases ved hjælp af den caseorienterede tilgang eller at studere mere generelle mønstre på tværs af mange cases i den variabel-orienterede tilgang.

\section{Figur 1. Komparativistens trade-off mellem antal cases og antal}

$$
\text { Antinl astobitist }
$$

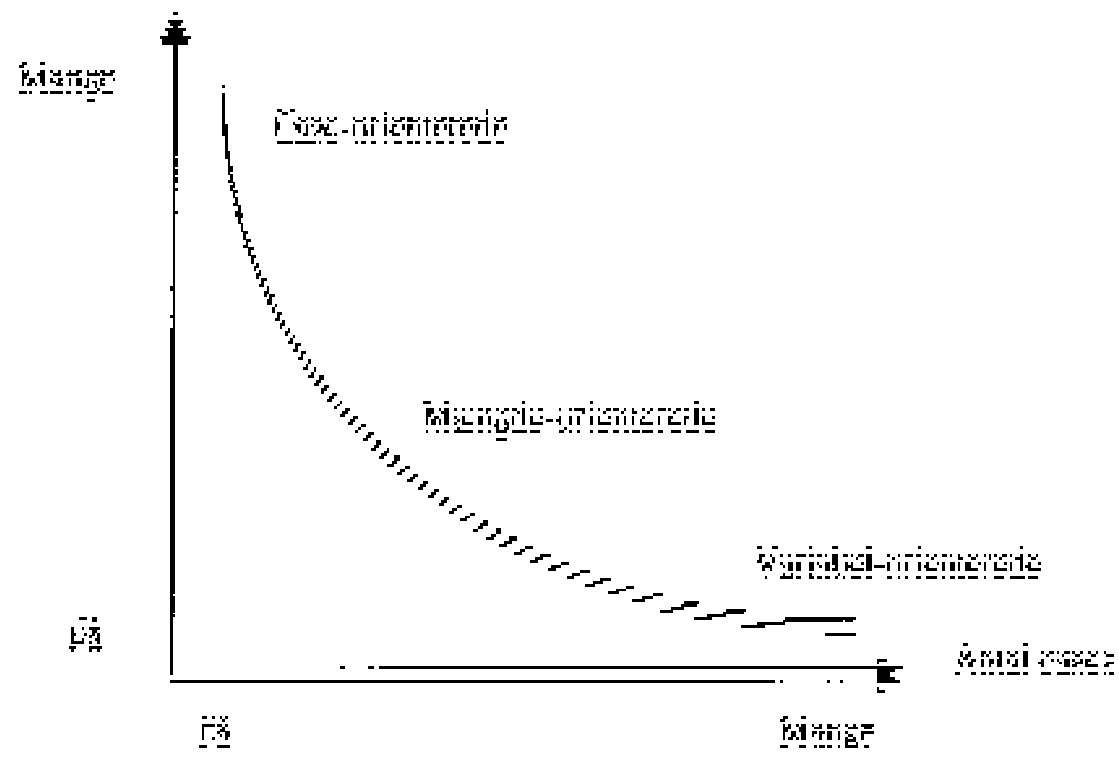

Kilde: Ragin (1994). 
De konventionelle case-orienterede og variabel-orienterede studiers velkendte styrke og svagheder går igen ved deres anvendelse i komparative studier ${ }^{3}$. I komparativ forskning er der dog et særligt træk ved mange undersøgelser, der udgør en udfordring for begge tilgange, nemlig antallet af cases. Ofte er det nemlig sådan, at der af forskellige årsager kan være et ønske om at sammenligne et medium antal lande. Tænk fx på en sammenligning af EU- eller OECD-lande, avancerede velfærdsstater, eller andre sådanne grupperinger, der af politiske eller teoretiske årsager er et påtrængende ønske om at studere. I sådanne tilfælde er det sjælden, at en gruppe forskere, endsige én forsker, formår at opnå en tilstrækkelig tilbundsgående forståelse af de inddragne cases til at kunne foretage en proper kvalitativ undersøgelse. Case-orienterede studier har traditionelt svært ved at håndtere mere end en håndfuld cases. Omvendt lider de variabel-orienterede tværnationale studier tilsvarende under for få cases til at kunne udføre robust, statistisk databehandling, også kendt som Small N-problemet i komparative studier.

I denne artikel vil vi argumentere for, at der tegner sig konturerne af en ny metode, der er velegnet til at studere netop sådanne situationer med et medium antal cases, nemlig brugen af fuzzy mængdelære 4 . Den mængde-orienterede metode placerer sig i figur 1 et sted mellem den case-orienterede og den variabel-orienterede. Den mængde-orienterede metode søger hverken at studere kompleksiteten i et fåtal af cases eller opstille generaliseringer på baggrund af mange cases, men snarere at studere forskelle og ligheder det vil sige diversitet - mellem et medium antal cases. Da denne indgangsvinkel stadig er forholdsvis ukendt inden for samfundsvidenskaberne, begrænser vi os til at se på brugen af fuzzy mængde-

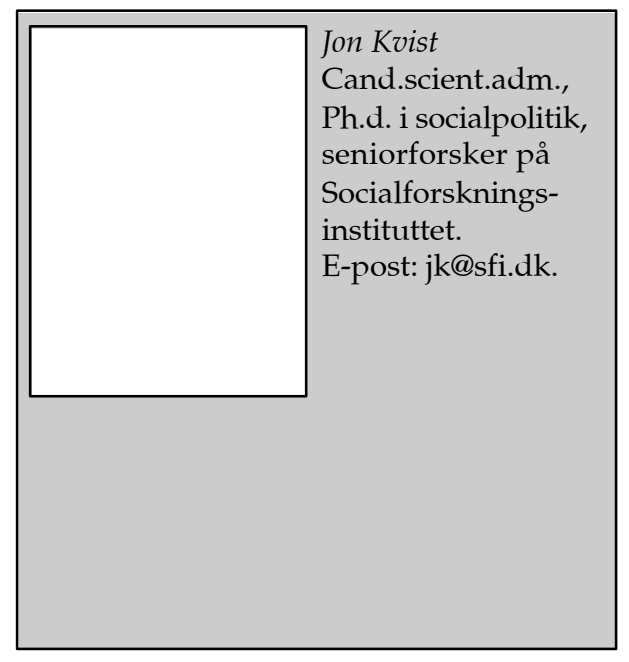

lære i studier af idealtyper. Idealtyper er hyppigt anvendt i samfundsvidenskaberne, da de, som Finn Collin (1996) påpeger, er velegnede til 'klassifikatoriske og ekspositoriske formål', som samfundsvidenskaberne næppe kunne være foruden.

Inden for den komparative velfærdsstatsforskning har idealtyperne oplevet noget nær en renæssance blandt andet på grund af danske sociologers og politologers bidrag (se fx Esping-Andersen 1990 og 1999, Borchorst 1994, Goul Andersen 1996, Abrahamson 1999, Siim 1999). Fx er det i diskussionen om relationen mellem velfærdsstaten og familien blevet gængs at skelne mellem forskellige idealtypiske familiepolitiske modeller såsom den socialdemokratiske, den konservative, og den liberale model ( $\mathrm{fx}$ Antonnen \& Sippilä 1996, Sippilä 1997, Esping-Andersen 1999, Kvist 1999, Sørensen 2000). Forenklet kan man sige, at disse tre vigtige europæiske familiepolitiske modeller vægter tre aspekter af socialpolitiske ordninger forskelligt, nemlig generøsiteten af børnefamilieydelser samt universaliteten og kvaliteten af børnepasning. Den socialdemokratiske model er da idealtypisk karakteriseret ved generøse børnefamilieydelser 
koblet med universel børnepasning af en forholdsvis høj kvalitet ${ }^{5}$. Statens mål er at udjævne levekårsmæssige forskelle mellem familier med og uden børn, mellem mænd og kvinder, og at sikre børnepasning til alle af en høj kvalitet. Sammen med et ønske om at fremme kvinders erhvervsdeltagelse har det været medvirkende til, at staten udbetaler relativt generøse ydelser og står for sikring af universel service og omsorg af en høj kvalitet.

Den konservative, familiepolitiske model er idealtypisk karakteriseret ved generøse børnefamilieydelser, mens offentlig støttet børnepasning er begrænset i omfang og ikke af samme kvalitet som i den socialdemokratiske model ${ }^{6}$. Modellen lægger vægt på familiens forpligtigelse såvel økonomisk som omsorgsmæssigt over for dens medlemmer. Staten søger at værne om familien i dens traditionelle udformning med manden som hovedforsørger og kvinden som omsorgsgiver. Staten sikrer derfor børnefamilier, især hvor manden har arbejde, et vist økonomisk grundlag. Samtidigt tager staten intet ansvar for omfanget eller kvaliteten af børnepasning, da det i modellens familiepolitiske ideologi ses som en opgave for moderen samt for kirken, frivillige velgørenhedsorganisationer og lokalsamfundet.

Den liberale familiepolitiske model har også en traditionel familieideologi med manden som hovedforsørger og kvinden som omsorgsgiver. Men i modsætning til den konservative model skal staten ikke blande sig i familiens anliggender. Familien skal søge at klare sig selv såvel økonomisk som omsorgsmæssigt. Staten skal kun tage sig midlertidigt af familier uden de nødvendige ressourcer. Kontante børnefamilieydelser består derfor dels af universelle, men ikke-generøse overførsler til alle børnefamilier, som i visse tilfælde aftrappes med eventuel anden indkomst, dels af børnefamilieydelser målrettet mod særlige grupper, især enlige mødre. Den liberale models familiepolitiske model kan på denne baggrund idealtypisk karakteriseres ved relativt ikke-generøse ydelser, og ingen omfattende offentligt støttet børnepasning. Sidstnævnte er af en lav kvalitet og baseret på hjælp fra frivillige organisationer og velgørenhed.

Det er ikke målet her nærmere at diskutere baggrunden, udformningen eller konsekvenserne af de tre familiepolitiske modeller (for nærmere se fx Björnberg 1999, Hatland 2000, Kjeldstad 2000, Sørensen 2000). De er selvsagt væsensforskellige. I stedet vil vi bruge de tre modeller som eksempler på idealtyper og vise, hvordan forskellige landes tilhørsforhold til idealtyper kan studeres ved hjælp af fuzzy mængdelære.

I det følgende vil vi kort opridse brugen og studiet af idealtyper. Dernæst præsenterer og diskuterer vi det første element af fuzzy mængdelære, nemlig ideen om at koncepter, aspekter og variable kan opfattes og operationaliseres som fuzzy mængder. Herefter behandler vi ideen om, at cases kan opfattes som konfigurationer af sådanne mængder, det andet element af fuzzy mængdelære. For at anskueliggøre den praktiske anvendelighed af fuzzy mængdelære fremdrager vi et studie af de nordiske landes seneste familiepolitiske udvikling i forhold til deres tilhørsforhold eller konformitet til den idealtypiske socialdemokratiske familiepolitiske model. Endeligt diskuteres fordele og svagheder ved fuzzy mængdelære som en ny metode i komparativ forskning.

\section{Idealtyper og metodiske indgangsvinkler}

Idealtyper kan ses som teoretiske konstruktioner, der gør det muligt at samle dele af en rig og kaotisk virkelighed i en 
begrebsmæssig forståelse ud fra et specifikt perspektiv. Brugen af idealtyper som en metode i samfundsvidenskaberne blev især fremmet af Max Weber ${ }^{7}$, der definerede en idealtype som:

... formed by the one-sided accentuation of one or more points of view and by the synthesis of a great many diffuse, discrete, more or less present and occasionally absent concrete individual phenomena, which are arranged according to those one-sidedly emphasized viewpoints into a unified analytical construct (Weber 1904: 90)

Idealtyper tjener et dobbelt formål. For det første er idealtyper brugbare til at beskrive virkeligheden. Empiriske repræsentationer af historiske hændelser er per definition farvet af den kaotiske og meningsløse virkelighed, 'the infinite flux'; kun idealtyper kan give eksakt viden (Weber 1904). For det andet giver idealtyper en målestok med hvilken den studerede virkelighed kan sammenholdes. Således er formålet med idealtyper ikke at præsentere den sociale verden som en sand eller historisk virkelighed, men snarere at give et sammenligningsinstrument, hvormed betydningen af virkeligheden kan vurderes (Weber 1904). Idealtyper er analytiske konstruktioner, der tjener samfundsforskere som målestok for at bestemme i hvilket omfang empiriske fænomener er ens og hvordan de adskiller sig fra nogle forudbestemte mål. På denne måde kan idealtyper ses som implicitte teorier, der hjælper forskere med at undersøge om faktiske empiriske fænomener er konforme og i overensstemmelse med antagne forudsætninger (Collin 1996:60-61).

Hvordan studerer man idealtyper ved hjælp af de konventionelle metoder?
Variabel-orienterede studier accelererer i generaliseringer, men giver ikke en forståelse for kompleksiteten af specifikke cases. Det er delvist, fordi disse metoder primært ser variable som enkeltstående identiteter, selv når disse variabler ifølge den idealtypiske logik rent faktisk interagerer meningsfyldt. I stedet for at skelne mellem sådanne konfigurationer af variable, fokuserer kvantitative metoder typisk på variation i givne variable over cases (se King et al. 1994 for et meget skarpt forsvar for den variabel-orienterede tilgang i komparativ forskning).

I case-orienterede studier er det derimod konfigurationer af variabler eller, med et andet ord, aspekter, der er hjørnestenen. Et holistisk billede af den sociale verden dominerer dermed de kvalitative metoder. Dette gør det muligt for caseorienterede forskere at undersøge, hvordan forskellige konfigurationer udgør forskellige typer snarere end gradsforskelle (se Yin 1994). Men dette komplekse syn på den sociale verden har sin pris. For case-orienterede forskere er prisen oftest et relativt begrænset antal cases i forhold til de fleste kvantitative studier samt vanskeligheder ved at formalisere graden af forskellighed mellem cases inden for samme type eller kategori. Samlet set får vi således, at variabel-orienterede forskere fokuserer på generaliseringer og variation mellem cases inden for kategorier, mens case-orienterede forskere fokuserer på kompleksitet og kategorisering af cases (Ragin 2000).

I mange komparative studier, der gør brug af idealtyper, behøver vi en metode, der kombinerer de to tilganges stærke sider i studiet af cases tilhørsforhold til idealtyper. Det vil sige det samtidige studie af hvilken type af kategorier empiriske fænomener hører under samt deres medlemskab af sådanne kategorier. Vi behøver en metode, der gør det muligt at studere kvantitativ og kvalitativ differen- 
tiering samtidigt. Det er også kendt som diversitet. Heldigvis begynder der at tegne sig nogle konturer af en sådan diversitetscentreret tilgang, nemlig brugen af fuzzy mængdelære i samfundsvidenskaberne.

Her vil vi demonstrere, hvordan denne nye metode kan bruges til at studere idealtyper ved først at skitsere hovedelementer og principper i fuzzy mængdelære, og, dernæst, ved at bruge fuzzy mængdelære i et simpelt illustrativt studie af landes tilhørsforhold til familiepolitiske modeller. Det vil vise, hvordan fuzzy mængdelære tillader det samtidige studie af forskellighed såvel i grad som i natur, altså diversitet. På grund af dette er fuzzy mængdelære særligt velegnet til at studere konformitet eller tilnærmelse til idealtyper, idet det kan vurdere en del af den historiske virkeligheds tilhørsforhold til idealtyper såvel kvalitativt som kvantitativt.

Fuzzy mængdelære blev lanceret i 1965 og har siden især fundet brug inden for naturvidenskab (Zadeh 1965). Inden for samfundsvidenskab har dets brug været meget sparsomt, om end mange af dets hovedideer blev formuleret allerede i 1950erne (Kaplan \& Schott 1951). Som Smithsom (1988) gør opmærksom på kan dette skyldes, at der har manglet en grundlæggende indføring i fuzzy mængdelære tilpasset samfundsvidenskaberne, hvorfor det er glædeligt, at Fuzzy-Set Social Science af den amerikanske professor i politologi og sociologi, Charles Ragin, udkom i år. Fuzzy mængdelære kan bruges både til kausale og beskrivende analyser. Her vil vi ikke komme ind på kausale forklaringsmodeller, men mere beskedent holde os til deskriptive studier af konformitet til idealtyper (se Ragin 2000 for brugen af fuzzy mængdelære i kausalanalyser). I hjertet af fuzzy mængdelæreanalyser er opfattelsen af cases som værende konstitu- eret af konfigurationer af aspekter således, at en forskel i blot ét aspekt kan resultere $\mathrm{i}$ en forskel i type og ikke blot i niveau. Forandring af ét element kan betyde en forandring af helheden. Fx vil to lande, der begge har universelle børnefamilieydelser, men hvor den ene har generøse ydelser og den anden ikke-generøse, være kvalitativt forskellige typer af velfærdsstater, hvad vi indledningsvist benævnte henholdsvis den socialdemokratiske og den liberale model. Den konservative model er karakteriseret ved selektive, men generøse børnefamilieydelser. På samme tid tillader fuzzy mængdelære delvist medlemskab af en case i en given konfiguration. Dermed gør brugen af fuzzy mængder det muligt både at studere forskelle i type og niveau samtidigt. Dette giver blandt andet mulighed for at analysere cases i forhold til deres relative medlemskab af specificerede idealtyper. I de næste par afsnit vil vi kort redegøre for, hvordan fuzzy mængdelære formelt operationaliserer koncepter og analytiske konstruktioner som idealtyper.

\section{Konceptualisering - formel operationalisering af verbale koncepter}

Det måske mest besnærende ved fuzzy mængdelære er, at den gør det muligt for forskere at bygge bro mellem sprogets og den empiriske analyses verdener på en ny måde. Som vi så ovenfor, har kvantitative forskere en tendens til at studere variabler, mens kvalitative forskere ser på aspekter af cases og deres mulige kombinationer. I modsætning hertil tager fuzzy mængder deres udgangspunkt i begreber eller koncepter. Koncepter er en del af det naturlige sprog. Inden for samfundsvidenskaberne er der et væld af teoretiske, kvalifikatoriske og andre abstrakte og verbale koncepter. Fx er der, inden for komparativ velfærdsstatsforsk- 
ning, teoretiske nøglekoncepter som 'medborgerskab' og 'sociale rettigheder' (Marshall 1950), kvalifikatoriske koncepter som 'universel' og 'generøs', og idealtyper som den 'socialdemokratiske velfærdsstat', der er givet ved universelle, generøse sociale rettigheder. Alle disse teoretiske koncepter og analytiske konstruktioner har en præcis mening for forskere, der bruger dem.

Forskellige cases har forskellige grader af medlemskab af idealtyper, når det fx gælder social medborgerskab. Og der er ikke nogen entydige grænser mellem, hvornår et land er karakteriseret ved socialt medborgerskab og hvornår det ikke er. Fuzzy mængdelære giver en analytisk ramme, som muliggør måling af verbalekancepterpåenprecism åde. Begre bet 'fuzzy' står altså ikke for upræcis eller tvetydig måling eller at koncepter er vage eller flertydige, men at koncepter kan operationaliseres som fuzzy mængder, hvori cases kan have delvist medlemskab. Fuzzy mængdelære giver derved en metode til at undersøge samfundsvidenskabelige koncepter, oven i købet en præcis metode til analyse af teoretiske koncepter.

\section{Fuzzy mængdelære}

Fuzzy mængdelære bygger på den klassiske mængdelære, ifølge hvilken verden kan anskues i sort-hvide modsætninger. Enten er en case medlem af mængden A (svarende til medlemsskabsværdien 1) eller ej (svarende til medlemsskabsværdien 0 og medlemskab i den komplementære mængde ikke-A). Fuzzy mængdelæres nyskabelse er at tillade delvist medlemskab af en mængde (svarende til en medlemsskabsværdi mellem 0 og 1). I praksis fungerer fuzzy mængder ved at tegne en kurve mellem to modsætninger, mellem A og ikke-A, mellem generøs og ikke-generøs. Information, substantiel viden og teorier hjælper forskeren med at tegne denne kurve. Funktionerne bag kurver i fuzzy mængder kan tage alle mulige former (lineær, S-funktion, Bellkurve m.v.), hvor den specifikke kurve så vidt muligt skal afspejle det givne koncept. Udarbejdelsen af en fuzzy mængde handler altså om at operationalisere et koncept mellem 0 og 1, mellem at være fuldt ude og at være fuldt inde i en given mængde.

Når forskeren skal tegne en kurve, der reflekterer det aktuelle koncept, bliver hendes opmærksomhed rettet mod selve konceptet snarere end mod variabler. Det bidrager til, at analysen kommer tæt på den teoretiske litteratur på området. Hvor det måske for en ekspert på børnepasning giver mening at tale om børnepasningskvalitet ved hjælp af en talmæssig værdi, fx ratioen af børn per ansat, er dette sjældent tilfældet for menigmand. For personer, der ikke er eksperter på kvaliteten af børnepasning, er det mere informativt at tale om 'lande med en høj kvalitet af børnepasning' end om 'lande, hvor ratioen af børn per ansat er under $X^{\prime}$. Dette indebærer ikke, at variabler ikke skal bruges, men snarere at de skal omformes til fuzzy mængder. Fx kan en børn/ansat ratio blive omformet til en fuzzy mængde over kvalitet. Dette involverer, at der bliver fastlagt nogle kvalitative brudpunkter, som hjælper med at oversætte rådata - i dette eksempel børn per ansat - til fuzzy mængder. Kvalitative brudpunkter indikerer, hvor der sker en kvalitativ forandring af det studerede koncept eller fænomen. I eksemplet sættes det første kvalitative brudpunkt fx hvor børnepasning har 'fuldt' lav kvalitet, hvorunder variation ikke er meningsfuld, da det ikke giver fornuft at skelne mellem i hvilket omfang ydelsen overstiger at have 'fuldt' lav kvalitet. Det andet kvalitative brudpunkt er hvor børnepasning har 'fuldt' høj kvalitet, over hvilket variation er meningsløs, da det tilsvarende ikke giver 
mening at skelne mellem i hvilket omfang ydelser overstiger at have 'fuldt' høj kvalitet. Det tredje kvalitative brudpunkt er det såkaldte krydspunkt, hvor børnepasning går fra at have mere høj kvalitet end lav kvalitet, se figur 2.

\section{Figur 2. Fuzzy mængder over høj og lav kvalitet i børnepasning}

\section{Pli 2 Yy medlenissskabavas fid $(0-1)$}

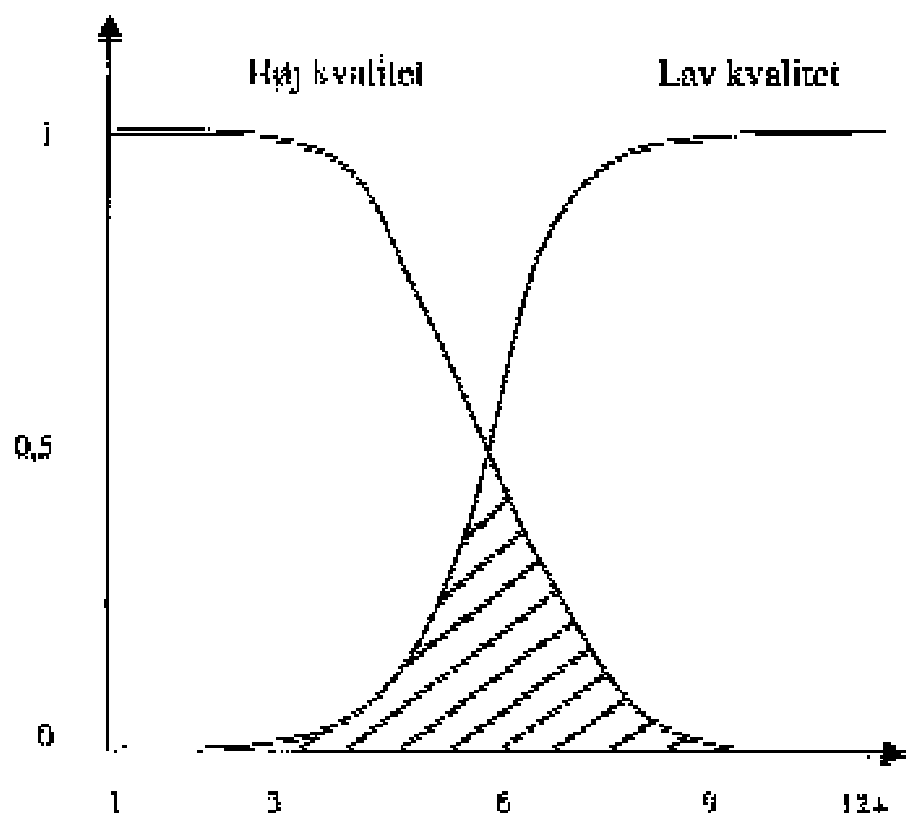

Antial batn per ansat:

Figur 2 viser fuzzy mængder for ideen om børnepasning af henholdsvis høj og lav kvalitet. Det ses, at grænsen mellem høj og lav kvalitet ikke blot er upræcis, men den er heller ikke unik. Efterhånden som antallet af børn per ansat stiger bevæger børnepasning sig ind i et område, hvor det samtidigt har træk af både høj og lav kvalitet. Børnepasning, der fx ikke har fuldt høj kvalitet, har også i et vist omfang lav kvalitet. Det skraverede område i figur 2 indikerer, hvor børnepasning både er medlem af regionerne med høj og lav kvalitet.

\section{Principper i fuzzy mængdelære}

Fuzzy mængdelære giver en kalkulus for kompatibilitet (regnestok for sammenlignelighed), der kan anvendes i analyser af idealtyper (for kausalanalyser, se Ragin 2000). Figur 3 viser nogle principper inden for fuzzy mængdelære, der er særligt anvendelige i studiet af idealtyper, nemlig principper til at finde værdier $i$ komplementær-, fælles-, og foreningsmængder. 
Figur 3. Illustrativ fremstilling af principper i fuzzy mængdelære

Negationsprincippct

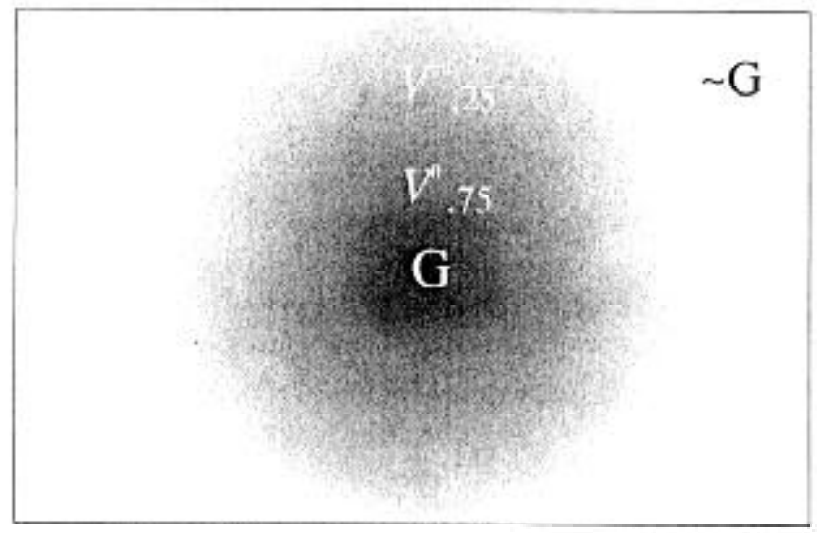

Minimumsprincippet

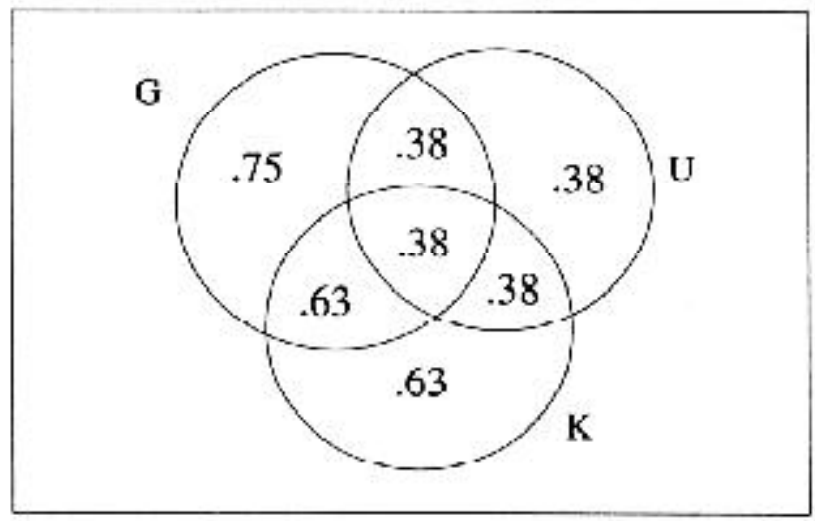

Maksimumsprincippet

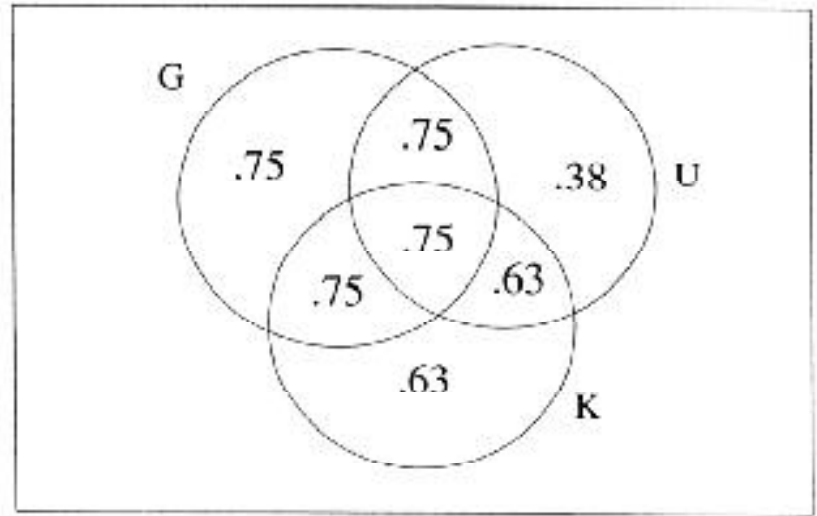


Principperne i fuzzy mængdelære er generaliseringer af principper inden for den klassiske mængdelære (se Zadeh 1965, Ragin 2000). Antag at en case $x$ har en medlemsskabsværdi vo i fuzzy mængde $\mathrm{G}$ over børnefamilieydelsers generøsitet, medlemsskabsværdi $v^{\text {u }}$ i fuzzy mængde $U$ over universaliteten af børnepasning, og medlemsskabsværdi $v^{\mathrm{k}} \mathrm{i}$ fuzzy mængde K over børnepasningens kvalitet:

- Værdi i komplementærmængde. Værdien af $x \mathrm{i} \sim \mathrm{G}$ er 1-vg, hvor $\sim \mathrm{G}$ står for den komplementære mængde ikke-G. Denne operation finder $x$ 's værdi i komplementærmængden til G, og benævnes negationsprincippet i fuzzy mængdelære.

- Værdi i fællesmængde. Værdien af $x \mathrm{i} \mathrm{G}^{*} \mathrm{U}^{*} \mathrm{~K}$, hvor '*' repræsenterer logisk OG, er minimumsværdien af $v^{\mathrm{g}}$, $v^{\mathrm{u}}$, og $v^{\mathrm{k}}$. I fuzzy mængdelære kaldes dette minimumsprincippet.

- $\quad$ Værdi i foreningsmængde. Værdien af $x$ i G+U+K, hvor '+' repræsenterer logisk ELLER, er maksimumsværdien af $v^{\mathrm{g}}, v^{\mathrm{u}}$, og $v^{\mathrm{k}}$. Dette kaldes maksimumsprincippet i fuzzy mængdelære.

Negationsprincippet er særligt værdifuldt, når man kun ser på ét aspekt af en case, fx generøsiteten eller ikke-generøsiteten af en case. En ydelse, der fx har medlemsskabsværdien 0,70 i fuzzy mængden over generøsitet har, ifølge negationsprincippet, medlemsskabsværdien 0,30 i den komplementære fuzzy mængde over ikke-generøsitet. Maksimums- og minimumsprincippet er derimod brugbare i studiet af cases medlemskab af analytiske konstruktioner såsom idealtyper, der består af specifikke konfigurationer af aspekter, (se næste afsnit). Fx kan minimumsprincippet anvendes til at undersøge i hvilket omfang et land er medlem af den socialdemokratiske familiepolitiske model med generøse børnefamilieydelser OG universel børnepasning OG børnepasning af en høj kvalitet. Minimumsprincippet følger logikken om, at kæden ikke er stærkere end dets svageste led. Et land er ikke mere medlem af en idealtypisk velfærdsmodel end dets laveste værdi på de identificerede konstituerende aspekter indikerer.

\section{Nabokoncepter og verbale kvalifikationskoncepter}

Fuzzy mængdelære gør det muligt at forbinde nabokoncepter med hinanden ved såkaldte undermængder. Hvor fx fuldt generøse og fuldt ikke-generøse mængder hver især udgør et yderpunkt, er der mange mellemliggende koncepter, der forbinder disse to kategorier. Afhængig af konceptets substans og det empiriske råmateriale kan man opsætte forskellige typer af fuzzy kategori intervaller (for nærmere se Ragin 2000). Her bruger vi en fuzzy mængde med ni værdier, idet vi har etableret de tre kvalitative brudpunkter $(0,0,5$ og 1$)$ og opdelt intervallet mellem 0 og 1 i sjettedele. De fundne kontinuerlige fuzzy medlemsskabsværdier indikerer på den baggrund medlemsskab på følgende vis:

- $\quad$ En værdi på 1 indikerer, at en case er 'fuldt' inde i mængden af fx lande med børnepasning af en 'høj' kvalitet;

- $\quad$ værdier mellem 0,84 og 0,99 indikerer, at en case er 'næsten fuldt' inde;

- 0,68 til 0,83 indikerer 'rimeligt' inde;

- 0,51 til 0,67 er 'mere eller mindre' inde;

- $\quad 0,5$ er krydspunktet, hvor en case 'hverken er mere inde end ude';

- 0,34 til 0,49 er 'mere eller mindre' ude;

- 0,18 til 0,33 er 'rimeligt' ude;

- 0,01 til 0,17 er 'næsten fuldt' ude; og

- 0 er 'fuldt' ude. 
Denne ni-værdis fuzzy mængde bliver brugt i resten af artiklen til at oversætte kontinuerlige fuzzy medlemsskabsværdier til verbale labels, fx 'fuldt' og 'næsten fuldt', der repræsenterer nabokoncepter eller undermængder af den givne mængde. For eksempel, hvis en ydelse opnår en fuzzy medlemsskabsværdi på 0,75 i mængden over generøsitet bliver det oversat til det verbale label 'rimeligt' generøst og en tilsvarende værdi på 0,60 oversættes til 'mere eller mindre' generøs. Dette illustrerer den anden oversættelse i fuzzy mængdelære. Hvor den første oversættelse, som tidligere beskrevet angår hvordan et teoretisk koncept kan omformes til en kurve, der forbinder to modsætninger, handler den anden oversættelse om hvordan en talmæssig værdi kan oversættes til et verbalt udsagn. Det vil sige, hvordan fuzzy medlemsskabsværdien for en case efter måling og beregning kan oversættes tilbage til naturligt sprog for præsentationsformål.

Sammenfattende har vi altså to typer af problemer forbundet med konventionelle forskningsstrategier i studiet af idealtyper. Studier, der bygger på klassisk mængdelære, behandler et koncept som en (arbitrær) dikotom variabel. Studier, der gør brug af traditionelle intervalskalaer, bruger ofte et induktivt mål, fx en median, til at definere, hvilke cases der er placeret henholdsvis relativt højt (over medianen) og relativt lavt (under medianen). Typisk lader sådanne studier også variablen være åben i begge ender, hvorved potentiel meningsløs variation bliver behandlet som reel. Substantiel og teoretisk viden er ofte ikke brugt til kritiske kvalitative distinktioner. Når kvalitative distinktioner og brudpunkter bliver brugt i konventionel forskning, kan de også overføres til fuzzy mængdelære analyser, se eksempler nedenfor. Fuzzy mængdelære bygger på principperne og ideen om kvalitative brudpunkter fra klassisk mængdelære, men ved at tillade delvist medlemskab i mængder tillader metoden, at samfundsvidenskabelige koncepter og fænomener kan studeres.

En potentiel svaghed ved fuzzy metoden er, at den kræver en høj grad af korrespondance mellem de valgte koncepter, der udgør idealtyperne, og fuzzy medlemsskabsværdier. Det er derfor vigtigt at give stor opmærksomhed til den analytiske konstruktion af idealtypen, kriterier for etablering af kvalitative brudpunkter og det empiriske materiale. Her bør forskeren som sagt ikke sætte sin lid til simple gennemsnit, medianer eller lignende relative mål kendt fra konventionel samfundsforskning, men bør være informeret af teoretisk og substantiel viden. Gennemsnit er stikprøveafhængige, koncepter og idealtyper er ikke. Forskerens direkte og aktive involvering lader hende åben for kritik af at vælge de forkerte aspekter, empiriske indikatorer, kvalitative brudpunkter og for ikke at oversætte data til verbale udsagn på passende vis. For at berige den videnskabelige dialog er det derfor afgørende, at forskeren er så åben som mulig omkring de trufne valg og deres betydning for undersøgelsen. Med andre ord er god forskningsetik vigtig her som i al øvrig forskning. Behovet er dog måske endnu mere påkrævet inden for komparativ forskning, hvor der ikke er samme omfang af empiri som inden for fx surveybaserede undersøgelser eller, mere generelt, inden for naturvidenskaberne. Ofte gør mangel på ideelle, sammenlignelige data det nødvendigt at bruge 'second-best data'. Når det er tilfældet, bør forskeren gøre eksplicit opmærksom på det.

Lad os illustrere det i eksemplet med de familiepolitiske modeller. Fra litteraturen har vi identificeret den socialdemokratiske velfærdsmodel på børnefamilieområdet som bestående af tre aspekter, nemlig generøse børnefamilieydelser 
samt universel børnepasning af en høj kvalitet. Det leder videre til identifikationen af empiriske indikatorer, kriterier for kvalitative brudpunkter og til en oversættelse af data til fuzzy medlemsskabsværdier efter følgende overvejelser:

- Generøsiteten af børnefamilieydelser er målt ved deres påvirkning af familiers disponible indkomst efter skat. Baseret på tre stiliserede familietyper (med forskellige antal af og alder på børn) finder vi den procentuelle, gennemsnitlige stigning i disponibel indkomst per barn forårsaget af børnefamilieydelser. På baggrund af nationale undersøgelser af husholdningsbudgetter har vi etableret nogle kvalitative brudpunkter for, hvornår ydelser kan bedømmes som dækkende eller generøse i forhold til de ekstra omkostninger, der er forbundet med at have børn ( $\mathrm{fx}$ CASA 1993, Hansen 1998). Hvis børnefamilieydelser får den disponible indkomst til at stige med mere end $6 \%$, bedømmer vi dette land til at være fuldt inde i mængden af lande med generøse børnefamilieydelser, mens en stigning på mindre end $1,4 \%$ bedømmes som triviel i forhold til omkostninger forbundet med at have børn og derfor fuldt ude af mængden.

- Universaliteten af børnepasning er målt ved andelen af børn i offentligt støttede børnehaver og familiedagpleje, uafhængigt af om dette er i den offentlige eller private sektor. Dermed negligeres den nogle gange omfattende brug af børnepasning i den informelle sektor, men denne har heller ikke direkte relevans for den konstruerede idealtype. Ikke desto mindre er der stadig en række forskellige ordninger for børn, der potentielt kan påvirke vores mål for børnepasningsdækning. For børn under 3 år er det især eksistensen af orlov (barsel, fædre, og forældre) og lignende ordninger, som invaliderer ethvert mål for dækning. Børn over 6 år går ofte i skole eller i førskoleordninger. For at nå frem til det mindst muligt farvede mål for børnepasning fokuserer vi derfor på børn mellem 3 og 6 år. Men det universelle aspekt er stadig ikke lige ud af landevejen. Målet med børnepasning er nemlig ikke at placere alle børn i børnepasningsordninger. I stedet for at bruge en intervalskala fra 0 til 100\% dækning, placerer vi derfor et kvalitativt brudpunkt ved $80 \%$ for at blive bedømt fuldt inde i mængden af lande med universel børnepasning og 20\% for at være fuldt ude. Det relativt høje øvre brudpunkt ved $80 \%$ søger at tage højde for den forholdsvis høje erhvervsfrekvens blandt nordiske mødre og bedstemødre, som traditionelt har stået for børnepasning (Leira 1992).

- Kvaliteten af børnepasning kan måles på mange forskellige måder. Empiriske amerikanske studier har identificeret antallet af børn per ansat som et af de nøgleparametre, som har betydning for børns velbefindende og senere udvikling (Howes 1997, Peisner-Feinberg og Burchinal 1997). Desværre har det ikke været muligt for os at finde data for andre og måske bedre kvalitetsmål såsom de ansattes uddannelse for alle landene i hele den studerede periode. Hvorvidt en ratio for børn per ansat kan ses som udtryk for børnepasning af en høj kvalitet afhænger blandt andet af børnenes alder og andre karakteristika. Gennemsnitligt for børn mellem 3 og 6 år er mindre end 3 børn per ansat et tegn på fuldt ud høj kvalitet, mindre end 6 
børn et tegn på god kvalitet, og mere end 9 børn et tegn på fuldt ud dårlig kvalitet (Brazelton 1992). På basis af disse kvalitative distinktioner fra konventionel empirisk samfundsforskning har vi etableret en fuzzy mængde over høj kvalitet i børnepasning med kvalitative brudpunkter og verbale labels, som fremgår af tabel 1.

Af tabel 1 fremgår de valgte empiriske indikatorer for de tre aspekter (generøsitet, universalitet, og kvalitet). Desuden kan man se, hvordan data oversættes til fuzzy medlemsskabsværdier og de ni verbale labels, jf. ovenfor.

\section{Konfiguration - idealtyper og cases som konfigurationer af aspekter}

Det andet element af fuzzy mængdelære, som vi kort vil berøre her, vedrører dets konfigurationelle eller holistiske syn (Ragin 2000). Kort sagt går det ud på, at man opfatter cases som bestående af konfigurationer af aspekter (eller mængder) således, at en forskel i et aspekt kan konstituere forskel i type og ikke blot i grad. Det konfigurationelle syn på cases ligger i hjertet af case-orienteret forskning, hvor forskellige aspekter bliver forstået i relation til hinanden og det hele, de tilsammen udgør (se Yin 1994). Hovedparten af konventionel variabel-orienteret forskning med et mindre antal observationer (eller cases) ser ikke en case's variabler i relation til hinanden. I stedet undersøger de variation mellem variable over cases (for et eksempel på ydelsers generøsitet se Scarpetta 1996). Variable ses således som uafhængige af hinanden, og når de ikke er det, søger forskere ofte af kontrollere for interaktionseffekter. I fuzzy mængdelære analyse af idealtyper er det imidlertid lige præcis kombinationen af variabler eller aspekter, der udgør den analytiske konstruktion, idealtypen.

Tabel 1. Specifikation af empiriske indikatorer og oversættelse af data til fuzzy medlemskabsværdier og verbale labels

Empiriske indikatorer:

Oversættelse af data til:

\begin{tabular}{|c|c|c|c|c|}
\hline $\begin{array}{l}\text { Generøsitet } \\
\text { målt ved den gennemsnitlige } \\
\text { forøgelse af disponibel } \\
\text { nettoindkomst } \\
\text { gundet Bømefamilieydelse } \\
\text { (\%) }\end{array}$ & $\begin{array}{l}\text { Universalitet } \\
\text { målt ved andelen af } \\
\text { børm mellem 3-6 år i } \\
\text { børmepasning (\%) }\end{array}$ & $\begin{array}{l}\text { Kvalitet } \\
\text { målt ved bøm: ansat } \\
\text { ratio i børnehaver }\end{array}$ & $\begin{array}{l}\text { Furzy } \\
\text { medlemsskabs- } \\
\text { værdier }\end{array}$ & Verbale labels \\
\hline$>6,00$ & $>80$ & $<3.00$ & 1 & Fuldt inde i mængden \\
\hline $5,20-5,99$ & $71-80$ & $3,00-3,99$ & 0,84-0,99 & Næsten fuldt inde i mængden \\
\hline $4,40-5,19$ & $61-70$ & $4,00-4,99$ & $0,68-0,83$ & Rimeligt inde i mængden \\
\hline $3,60-4,39$ & $51-60$ & $5,00-5,99$ & $0,51-0,67$ & Mere eller mindre inde i mængden \\
\hline $3,50-3,59$ & 50 & 6,00 & 0,50 & Krydspunkt \\
\hline $2,80-3,49$ & $40-49$ & $6,01-7,00$ & $0,34-0,49$ & Mere eller mindre ude af mængden \\
\hline $2,10-2,79$ & $30-39$ & $7,01-8,00$ & $0,18-0,33$ & Rimeligt ude af mængden \\
\hline $1,40-2,09$ & $20-29$ & $8,01-8,99$ & $0,01-0,17$ & Næsten fuldt ude af mængden \\
\hline$<1.40$ & $<20$ & $>9,00$ & 0 & Fuldt ude af mængden \\
\hline
\end{tabular}


Tabel 2. Det analytiske egenskabsrum for familiepolitiske modeller

\begin{tabular}{|c|c|c|c|}
\hline $\begin{array}{l}\text { Generøsitet af } \\
\text { børnefamilieydelser }\end{array}$ & $\begin{array}{l}\text { Universalitet af } \\
\text { børnepasning }\end{array}$ & $\begin{array}{l}\text { Kvalitet af } \\
\text { børnepasning }\end{array}$ & $\begin{array}{l}\text { Familiepolitisk } \\
\text { model }\end{array}$ \\
\hline G (høj) & U (omfattende) & $\mathrm{K}(\mathrm{h} \varnothing \mathrm{j})$ & $\mathrm{G} * \mathrm{U} * \mathrm{~K}$ \\
\hline$G(h ø j)$ & U (omfattende) & $\sim \mathrm{K}(\mathrm{lav})$ & $\mathrm{G}^{*} \mathrm{U}^{*} \sim \mathrm{K}$ \\
\hline $\mathrm{G}(\mathrm{h} \varnothing \mathrm{j})$ & $\sim \mathrm{U}($ sparsom $)$ & $\mathrm{K}(\mathrm{h} \varnothing \mathrm{j})$ & $\mathrm{G}^{*} \sim \mathrm{U} * \mathrm{~K}$ \\
\hline$G(h ø j)$ & $\sim \mathrm{U}($ sparsom $)$ & $\sim \mathrm{K}(\mathrm{lav})$ & $\mathrm{G}^{*} \sim \mathrm{U}^{*} \sim \mathrm{K}$ \\
\hline$\sim \mathrm{G}(\mathrm{lav})$ & $\mathrm{U}$ (omfattende) & $\mathrm{K}(\mathrm{h} \varnothing \mathrm{j})$ & $\sim \mathrm{G}^{*} \mathrm{U} * \mathrm{~K}$ \\
\hline$\sim \mathrm{G}$ (lav) & U (omfattende) & $\sim \mathrm{K}(\mathrm{lav})$ & $\sim \mathrm{G} * \mathrm{U} * \sim \mathrm{K}$ \\
\hline$\sim \mathrm{G}$ (lav) & $\sim \mathrm{U}($ sparsom $)$ & $\mathrm{K}(\mathrm{h} \varnothing \mathrm{j})$ & $\sim \mathrm{G}^{*} \sim \mathrm{U}^{*} \mathrm{~K}$ \\
\hline$\sim \mathrm{G}$ (lav) & $\sim \mathrm{U}($ sparsom $)$ & $\sim \mathrm{K}(\mathrm{lav})$ & $\sim \mathrm{G}^{*} \sim \mathrm{U}^{*} \sim \mathrm{K}$ \\
\hline
\end{tabular}

\section{Det analytiske egenskabsrum}

Som beskrevet indledningsvist kan man af pædagogiske hensyn identificere tre aspekter (eller variable, eller mængder), der er essentielle for en forståelse af den socialdemokratiske familiepolitiske model. Relativt generøse børnefamilieydelser og universel børnepasning af en høj kvalitet konstituerer tilsammen den idealtypiske socialdemokratiske model. I princippet kan disse tre aspekter kombineres på $2^{3}$, dvs. otte måder, der præsenterer det analytiske egenskabsrum (Ragin 2000, se også Lazarsfeld 1937).

Tabel 2 over det analytiske egenskabsrum præsenterer de mulige kombinationer af de tre aspekter og kan på den vis ses som en liste over det samlede antal mulige analytiske konstruktioner, eller idealtyper, som kan sættes op på baggrund af de tre aspekter. Nogle af disse idealtyper vil imidlertid mangle empiriske cases eller være irrelevante, men ikke desto mindre hjælper det analytiske egenskabsrum forskeren med at danne et overblik over området (derudover kan egenskabsrummet reduceres ved hjælp af aksiomer i mængdelære, se Ragin 2000). Dette syn på cases som konfigurationer af aspekter implementerer ideen om at en forskel i et enkelt aspekt mellem to cases kan udgøre en forskel i type, en kvalitativ forskel. Derudover viser tabel
2, at aspekter ikke skal ses som uafhængige, enkeltstående variabler, men snarere som elementer i konfigurationer.

Den socialdemokratiske familiepolitiske model svarer i denne præsentation af det analytiske egenskabsrum til den første model i tabel 2. Hvis vi omformer aspekterne til fuzzy mængder, får vi udtrykt med termer fra fuzzy mængdelære, at den socialdemokratiske model svarer til den idealtypiske placering: $\mathrm{G}^{*} \mathrm{U}^{*} \mathrm{~K}$, også kaldet generøse børnefamilieydelser OG universel børnepasning OG høj kvalitet af børnepasning. Den konservative familiepolitiske model svarer til den fjerde model, $\mathrm{G}^{*} \sim \mathrm{U}^{*} \sim \mathrm{K}$, og den liberale model til den sidste model i tabel 2, $\sim G^{*} \sim U^{*} \sim K$. Hvorvidt og i hvilket omfang enkelte lande nærmer sig den ene eller anden model kan studeres nærmere ved hjælp af fuzzy mængdelære. Det vil vi se nærmere på i næste afsnit.

\section{Kategorisering - hvordan cases tilnærmer sig idealtyper}

Det konfigurationelle syn på cases har altså givet os en typologi over familiepolitiske idealtyper. Som sagt vil ikke alle idealtyper være meningsfulde og/eller have empiriske cases, ligesom det i sagens natur er yderst sjældent et konkret fænomen vil nærme sig et perfekt match på idealtypen. Ved at kombinere fuzzy mængder over de forskellige aspekter 
med det konfigurationelle syn på cases, giver fuzzy mængdelære os en mulighed for at undersøge, hvilken idealtype cases tilhører, samt deres grad af medlemskab af andre idealtyper. Fuzzy mængdelære giver med andre ord et analytisk redskab til samtidigt at studere såvel kvantitative som kvalitative forskelle og forandringer. Kvantitativ forandring sker når en case's medlemskab af en idealtype skifter over tid - graden af medlemskab forandres. Kvalitativ forandring opstår når en case går fra at have været tættest på en idealtype til at være tættere på en anden. Det sker når medlemsskabsværdier passerer over et eller flere af de kvalitative krydspunkter for aspekterne. Det er blandt andet derfor, at krydspunkterne opfattes som kvalitative brudpunkter.

Samtidigt skal det selvfølgelig holdes for øje, at en kvalitativ forandring kun sker i det omfang, at krydspunkterne har reel mening. I vores eksempel med ydelsers generøsitet vil et skift fra 0,51 til 0,49 således kun være en triviel forandring for så vidt, at casen blot har bevæget sig fra at være det svagest mulige medlem af en type til at blive det svageste medlem af en anden type. I andre tilfælde, hvor krydspunktet har større substantiel eller teoretisk mening, kan sådanne skift imidlertid godt udlægges som reelle kvalitative forandringer. I næste afsnit vil vi for illustrative formål vise, hvordan de nordiske landes familiepolitiske udvikling kan beskrives og analyseres ved hjælp af de gennemgåede elementer af fuzzy mængdelære.

\section{De nordiske landes familiepolitiske udvikling i 1990erne analyseret ved hjælp af fuzzy mængdelære}

På baggrund af de tidligere etablerede fuzzy mængder over generøsitet i børnefamilieydelser samt universaliteten og kvaliteten af børnepasning, jf. tabel 1, kan man oversætte rådata for de empiriske indikatorer til fuzzy medlemsskabsværdier. Materialet bygger på undersøgelser af socialpolitiske ordninger i Europa (Hansen div. år, Nososko div. år). På baggrund af de fundne fuzzy medlemsskabsværdier i tabel 3 (se næste side) kan vi nu analysere, hvorvidt den seneste historiske udvikling i de nordiske landes familiepolitik er i overensstemmelse med den socialdemokratiske familiepolitiske model.

\section{Generøse børnefamilieydelser}

I 1990 var Danmark det mindst generøse af de nordiske lande. I 1991 blev børnefamilieydelsen øget og den særlige ydelse for småbørn udvidet fra 0-3 årige til 0-6 årige. Sammen med andre forbedringer gennem 1990erne blev Danmark 'rimeligt' generøs i 1998.

I 1994 var Finland 'fuldt generøs' og klart det mest generøse af de nordiske lande. Børnefamilieydelserne var ikke underlagt de generelle nedskæringer i de tidlige 1990ere. I 1994 blev ydelserne faktisk øget med ikke mindre end $40 \%$, da den kontante støtte til børnefamilier gik fra at være en skatteydelse til at være en direkte ydelser med et ekstra supplement for enlige forældre. Børnefamilieydelsen forblev nominelt den samme fra 1994 til 1995, hvilket betød en mindre nedgang i generøsitet. I 1996 blev ydelserne reduceret kraftigt og ikke indekseret det følgende år. Selvom Finland derfor faldt over 1990erne fra at være 'fuldt generøs' til 'rimeligt generøs' i dag, er det stadig det mest generøse af de nordiske lande.

Sverige var 'næsten fuldt generøs' i de tidligere 1990ere. Selvom krisepakkerne betød markante nedskæringer i de fleste sociale ordninger, gjaldt det i første omgang ikke børnefamilieydelserne, som faktisk steg to gange som led i en reform af skatter og ydelser i 1991. Men derefter blev børnefamilieydelserne gen- 
Tabel 3. Nordiske landes grad af generøsitet, universalitet og kvalitet samt komformitet til den socialdemokratiske familiepolitiske model, 1990-99.

\begin{tabular}{|c|c|c|c|c|c|}
\hline Land & År & $\begin{array}{c}\text { Generøsitet af } \\
\text { bømefamilieydelser } \\
\text { (G) }\end{array}$ & $\begin{array}{l}\text { Universalitet af } \\
\text { børmepasning } \\
\text { (U) }\end{array}$ & $\begin{array}{l}\text { Kvalitet af } \\
\text { børmepasning } \\
\text { (K) }\end{array}$ & $\begin{array}{c}\text { Den } \\
\text { socialdemokratiske } \\
\text { familiepolitiske model } \\
\left(\mathrm{G}^{*} \mathrm{U}^{*} \mathrm{~K}\right)\end{array}$ \\
\hline \multirow[t]{5}{*}{ Danmark } & $1990 / 91$ & 0,56 & 0,87 & 0,53 & 0,53 \\
\hline & $1992 / 93$ & 0,61 & 0,94 & 0,62 & 0,61 \\
\hline & 1994/95 & 0,65 & 0,99 & 0,71 & 0,65 \\
\hline & 1996/97 & 0,67 & 1,00 & 0,71 & 0,67 \\
\hline & 1998/99 & 0,68 & 1,00 & 0,71 & 0,68 \\
\hline \multirow[t]{5}{*}{ Finland } & $1990 / 91$ & - & 0,63 & 0,51 & 0,51 \\
\hline & $1992 / 93$ & - & 0,51 & 0,57 & 0,51 \\
\hline & 1994/95 & 1,00 & 0,58 & 0,63 & 0,58 \\
\hline & 1996/97 & 0,88 & 0,78 & 0,63 & 0,63 \\
\hline & 1998/99 & 0,79 & 0,81 & 0,63 & 0,63 \\
\hline \multirow[t]{5}{*}{ Norge } & $1990 / 91$ & - & 0,62 & 0,75 & 0,62 \\
\hline & $1992 / 93$ & - & 0,68 & 0,75 & 0,68 \\
\hline & 1994/95 & - & 0,68 & 0,75 & 0,68 \\
\hline & 1996/97 & - & 0,87 & 0,75 & 0,75 \\
\hline & 1998/99 & - & 0,91 & 0,75 & 0,75 \\
\hline \multirow[t]{5}{*}{ Sverige } & $1990 / 91$ & 0,89 & 0,73 & 0,71 & 0,71 \\
\hline & $1992 / 93$ & 0,84 & 0,71 & 0,67 & 0,67 \\
\hline & $1994 / 95$ & 0,76 & 0,87 & 0,63 & 0,63 \\
\hline & 1996/97 & 0,52 & 1,00 & 0,63 & 0,52 \\
\hline & 1998/99 & 0,67 & 0,97 & 0,63 & 0,63 \\
\hline
\end{tabular}

Kilder: Hansen, diverse år; NOSOSKO, diverse år.

Noter: Desværre er der ingen data til rådighed for generøsitet i Norge, generøsitet i Finland 1990-93 og for kvaliteten af børnepasning fra 1996 og frem. Det er dog usandsynligt, at Finlands konformitet til den socialdemokratiske familiepolitiske model i $1990-93 \mathrm{er}$ påvirket af mangel på mål for generøsitet, da dets børnefamilieydelser var meget høje i starten af 1990eme. Data på børnepasningskvalitet for 1996-99 er sat på samme niveau som i 1993/94, hvilket er en heroisk antagelse i lyset af den markante ekspansion i antallet af børmepasningspladser, der sandsynligvis har betydet et trade-off med kvalitet som er målt her ved børm per ansat.

tagne gange skåret ned, og som et resultat heraf var Sverige i 1997 kun på grænsen til at kunne kaldes generøs. Det var måske smertetærsklen, for i 1998 førte folkeligt pres, bedre økonomi og politisk stemmefiskeri til øgede børnefamilieydelser, som i dag er tæt på at være 'rimeligt generøse'.

\section{Universalitet af børnepasning}

I 1990 var børnepasningen i Danmark 'næsten fuldt' universel, og siden 1996 har den været 'fuldt' universel. Ventelister har dog eksisteret igennem 1990erne. Dette skyldes til dels at børnepasning ligesom i de øvrige nordiske lande er et kommunalt anliggende. På baggrund af regeringens kraftige udmeldinger, subsidier og et ønske fra kommunerne om at beholde og tiltrække børnefamilier er antallet af børnepasningspladser dog steget kraftigt. Ikke desto mindre har øget fertilitet og lavere ledighed resulteret $\mathrm{i}$ ekstra efterspørgsel efter børnepasning, som kun delvis er blevet imødegået af forbedrede orlovsordninger i 1994, som siden er blevet reduceret og nu afskaffet. Ventelisterne er således kun faldet fra cirka 16.000 i 1996 til 12.000 i 1998 på trods af den kraftige ekspansion og introduktion af pasningsgaranti i de fleste kommuner. 
I Finland har der været pasningsgaranti i længere tid, da kommunerne har haft en pligt til at tilbyde børnepasningsmulighed for børn under 3 år. Finland var alligevel kun 'mere eller mindre' universel i 1990. Efterhånden som arbejdsløsheden steg kraftigt i de følgende år, er andelen af børn i børnepasning - og dermed graden af universalitet - faldet drastisk. Dette er delvist fordi ledige valgte at passe egne børn for at spare penge, og delvis fordi kommuner forhindrede børn af ledige i at få pladser. Eksklusionen af ledige fra at få del i sociale serviceydelser går direkte mod solidaritetsprincippet, der idealtypisk er forbundet med den socialdemokratiske velfærdsmodel. I et kursskifte blev dækningen og fleksibiliteten af børnepasning øget for at styrke mulighederne for at tage erhvervsarbejde. Fx blev pasningsgarantien i 1996 udvidet til at omfatte alle børn under 7 år, resulterende i en betydelig øgning af antal børn i børnepasning med cirka 27.000 fra 1995 til 1996. Kombineret med en bedre økonomi og højere erhvervsdeltagelse blandt kvinder betød dette, at dækningen af finsk børnepasning steg kraftigt til at blive 'rimeligt' universel siden 1997.

I Sverige steg antallet af børn i børnepasning fra 1990 til 1997 med ikke mindre end 155.000 børn mellem 0-6 år svarende til $42 \%$. Denne dramatiske stigning er et resultat af en kraftig ekspansion i børnehaver samt færre restriktioner på privat børnepasning. Sveriges grad af universalitet er også steget fra at være 'rimeligt universel' i 1990 til at blive 'fuldt universel' i 1996, men er bl.a. på grund af besparelser i det offentlige budget i 1997-98 gået til at være 'næsten fuldt' universel. Ligesom i Finland har forældre i Sverige ret til børnepasning hvis de arbejder eller studerer, om end ledige og ikke-ledige kan blive behandlet forskelligt på grund af lokal autonomi.
Med den mindste andel af 3-6 årige i børnepasning havde Norge i 1990 'mere eller mindre' universel børnepasning, der steg marginalt til at blive 'rimeligt' universel fra 1992 til 1996. Det stemmer overens med billedet af landet som det mest traditionelle af de nordiske lande. Historisk har Norge ikke gennemlevet det samme skift fra at børn bliver passet af mødre og bedstemødre til at blive passet i børnehaver og dagpleje som det fx skete i Danmark og Sverige i 1960erne og 1970erne. Men dette ser ud til at være under forandring i 1990erne. Høj fertilitet og øget erhvervsdeltagelse blandt kvinder har øget efterspørgslen efter offentligt støttet børnepasning. Da de 6 årige i 1997 blev indskrevet i skoler, betød det flere børnepasningspladser og afskaffelse af ventelister for de 3-5 årige. Omvendt har forbedringer af forældreorlov og lignende ordninger reduceret efterspørgslen efter børnepasning, især for 0-2 årige. Den første af disse to modsatrettede tendenser har fået overtaget mod slutningen af årtiet, da der i 1997 sker en dramatisk stigning $i$ andelen af småbørn i børnepasning, der i dag er 'næsten fuldt' universelt. Med andre ord er Norge ikke længere så traditionelt på dette område af familiepolitikken, hvor det ikke længere adskiller sig fra de øvrige nordiske lande.

\section{Kvalitet af børnepasning}

Ingen af de nordiske lande kan siges at have børnepasning af 'fuldt ud' høj kvalitet, når kvalitet måles ved antal børn per ansat. Danmark har gået fra at have 'mere eller mindre' høj kvalitet i 1990 til at have 'rimelig' høj kvalitet i 1993, eftersom ratio af børn per ansat faldt fra 5,8 til 4,7. I de samme år forværredes Finlands kvalitet, hvor børn/ansat ratio gik fra 5 til 5,2. Selvom Norge kun havde en 'rimelig' høj kvalitet i børnepasning, var det stadig det nordiske land med den 
bedste kvalitet med 4,5 børn per ansat i både 1990 og 1993. Sverige faldt i den samme periode fra at have 'rimelig' høj kvalitet til at få 'mere eller mindre' høj kvalitet. Desværre er der ingen nyere data. Men det er usandsynligt, at kvaliteten er steget under den kraftige ekspansion i børnepasning i alle landene. Snarere er det sandsynligt, at målet om af opnå universel børnepasning delvis er opnået gennem kompromiser på kvaliteten af børnepasning, der allerede i starten af perioden ikke var tilfredsstillende i forhold til den opstillede idealtypes krav.

\section{Konformitet til den socialdemokratiske familiepolitiske model}

I 1990erne er der sket betydelige forandringer inden for det familiepolitiske område i de nordiske lande, hvad angår generøsiteten af børnefamilieydelser og universaliteten af børnepasning. De beskrevne forandringer har dog ikke resulteret $i$, at nogle lande er blevet ekskluderet fra den socialdemokratiske familiepolitiske model, om end Sverige efter at have været i førertrøjen i 1990 blev et 'grænsetilfælde' i 1996. Siden er Sverige kommet tættere på den idealtypiske model gennem forbedringer af dets familiepolitik, især generøsiteten af børnefamilieydelser, men det er stadig et stykke fra niveauet i 1990 og stadig ikke i front. Norge har udvist størst stabilitet med en gradvis forbedring fra at være 'mere eller mindre' til at komme 'rimeligt' tæt på den socialdemokratiske familiepolitiske model. Finland var knapt et medlem af modellen i starten af årtiet, bl.a. på grund af nedskæringspolitikker i kølvandet på svære økonomiske problemer. Finland er $i$ anden halvdel af 1990erne kommet sig over krisen, har forbedret dele af dets familiepolitik og er nu 'rimeligt' tæt på den socialdemokratiske model. Ingen af de nordiske lande er dog tæt på den idealtypiske socialdemokratiske familiepolitiske model.

Det skyldes ikke mindst, at mange af de nordiske lande har oplevet en sej kamp på børnepasningsområdet. De har alle foretaget en markant udvidelse af antallet af børnepasningspladser, men på grund af en kombination af øget fertilitet, arbejdsløshed og nye eller forbedrede orlovsordninger og pasningsydelser har dette ikke givet udslag i tilsvarende stigning i graden af universalitet. Ikke desto mindre er universalitet det eneste område, hvor alle lande har oplevet en fremgang, og Danmark og Sverige har i dag et 'fuldt' universelt børnepasningssystem. Prisen for udvidelsen af børnepasningspladser er måske desværre forværret kvalitet i pasningstilbudene. Danmark er således det eneste land, hvor børn/ansat ratio er forbedret, men det er samtidigt også landet med den mindste andel af uddannet personale, et andet kvalitetsmål. Alle fire lande kan foretage betydelige forbedringer på kvaliteten af børnepasning, før de kan regnes som havende fuldt ud god kvalitet.

Overordnet set tegner reformerne ikke et klart mønster i de fire lande. På trods af betydelige nedskæringer i Finland er det stadig det mest generøse af de nordiske lande. Generelt set har Danmark og i et mindre omfang Norge forbedret deres politik over for børnefamilier. De mest tydelige og direkte nedskæringer er introduceret i Sverige, og, om end mindre synligt, i Finland. Begge disse lande har dog i de senere år forbedret dele af deres familiepolitik. Med andre ord kan vi identificere både forbedringer og nedskæringer i de fire lande, som ikke slavisk følger landenes økonomiske situation, men også andre faktorer. Slutteligt kan vi se, at reformerne ikke har resulteret i en større grad af konvergens eller divergens mellem de nationale børnefamiliepoli- 
tiske systemer i deres generøsitet, universalitet eller kvalitet.

\section{Diskussion}

Ud over de allerede anførte forskelle mellem fuzzy mængdelære og konventionelle kvalitative og kvantitative metoder skal der blot anføres et par enkelte mere, der relaterer sig til fuzzy mængdelære i forhold til intervalskalaer og sandsynlighedsregning samt til betragtninger af videnskabsteoretisk og empirisk karakter i forhold til andre komparative studier af familiepolitik.

Fuzzy mængdelæres brug af nabokoncepter skal ikke forveksles med konventionelle måleskalaer, som er en dominerende strategi i den kvantitative del af samfundsvidenskaberne for at undgå arbitrær inddeling. Nominelle eller kategorielle skalaer har faste og diskrete grænser for ender af intervaller. Dette er ikke tilfældet for fuzzy undermængder, hvor fx den 'rimeligt' generøse undermængde har flydende grænser og overlapper med det 'mere eller mindre' generøse undermængde i nedre ende og med 'næsten fuldt' generøse undermængde i øvre ende. Og for nominelle skalaer angives i sagens natur ikke graden af medlemsskab. Ordinal-, interval- og ratioskalaer kan give mål for en observations grad af medlemskab af en kategori, men de kan ikke håndtere flere og overlappende kategorier.

Fuzzy mængdelære skal heller ikke forveksles med sandsynlighedsregning. Sandsynligheder giver vidnesbyrd for eller imod en hændelse indtræffer. Fuzzy mængdelære giver derimod vidnesbyrd for graden af en hændelses forekomst, for medlemsskabet i en mængde over sådanne hændelser. Dette er en simpel, men vigtig forskel.

Videnskabsteoretisk placerer brugen af idealtyper og fuzzy mængdelære sig i spændingsfeltet mellem nomotetiske og ideografiske teorier og metoder. Som $\mathrm{fx}$ Ringer (1997) gør sig til talsmand for, så søger idealtypen i den weberianske forstand netop at bygge bro mellem en forklarende og en fortolkende tradition inden for samfundsvidenskaberne. Potentialet for fuzzy mængdelære ligger ligeledes ikke i at opstille universelle lovmæssigheder, som er det positivistiske ideal for nomotetiske og variabel-orienterede studier. Den grundlæggende antagelse i fuzzy mængdelære om at enkelte dele af virkeligheden interagerer meningsfyldt i konfigurationer, bygger på case-orienterede metoders og ideografiske teoriers syn på, at verden skal anskues holistisk. Tilsvarende bryder den aktive dialog mellem empiri og teori i udarbejdelsen af fuzzy mængder med den hypotetisk-deduktive metode i de variabel-orienterede studier (se Goldthorpe 1997, Ragin 1997, Shalev 1998 for en diskussion af en tidlig udgave af mængdelære (QCA, se også Wad dette nummer) versus konventionelle statistiske metoder).

Samtidigt adskiller fuzzy mængdelære sig også fra visse ideografiske teorier og case-orienterede studier ved sin insisteren på, at virkeligheden kan studeres formelt og matematisk. Hermed tager fuzzy mængdelære til dels et positivistisk udtryk. Det er på denne baggrund, at Ragin (2000: 4) hævder, at fuzzy mængdelære kan anskues som en 'fortolkende algebra', der giver nye muligheder for at 'udforske den sociale virkelighed' i forhold til eksisterende, konventionelle metoder. Hermed søges ikke at monopolisere samfundsvidenskaberne, men snarere at give komplementære redskaber til forskere, hvis primære interesse er at udforske social diversitet og bidrage til teoriudvikling snarere end fortolkning af enkeltstående, sociale fænomeners betydning (case-orienterede tilgange), eller at identificere brede mønstre, teste og raf- 
finere teorier og bidrage til forudsigelser (variabel-orienterede) (for nærmere se Ragin 1994, 2000).

Værdien af fuzzy mængdelære kan illustreres ved samspillet mellem eller komplementariteten af empiriske studier af den familiepolitiske udvikling, der gør brug af forskellige metodiske udgangspunkter. Case-orienterede studier har de seneste ti år bidraget væsentligt til teoriudvikling inden for den komparative velfærdsstatslitteratur, ikke mindst feministiske studier har klargjort fremkomsten af distinkte, nationale familiepolitiske systemer - typisk udtrykt ved nye eller modificerede idealtyper - og hvordan disse påvirker, især kvinders, livschancer i form af adgang til lønnet arbejde, muligheder for at kombinere arbejds- og familieliv m.v. (fx Lewis 1992, Orloff 1993, Hobson et al. 2000). Dette har medført en grundlæggende nytænkning inden for litteraturen, hvor nye spørgsmål er blevet stillet og søgt besvaret i mere variabel-orienterede studier igen ofte ved brug af idealtyper ( $f x$ Esping-Andersen 1999). På denne vis har case- og variabel-orienterede studier spillet sammen til at skabe en bedre forståelse for herkomsten, konsekvenserne og den høje grad af diversitet, der præger nationale, familiepolitiske systemer.

Fuzzy mængdelære giver nye måder at analysere sådanne forhold for et medium antal cases, der ikke er muligt for caseog variabel-orienterede studier. Denne artikel har koncentreret sig om studiet af den empiriske virkeligheds konformitet til teoretiske koncepter og idealtyper, dvs. hvordan diversitet kan fortolkes på tværs af sted og over tid. I analysen ovenfor fremgik, hvordan alle de nordiske lande forblev medlemmer af den idealtypiske, socialdemokratiske, familiepolitiske model i 1990erne, men at dette dækkede over vigtige udviklingstræk. Fx skete der i alle lande en væsentlig forbedring af børnepasningens universalitet, og i Sverige en betydelig reduktion af børnefamilieydelsers generøsitet. Som konsekvens heraf er Norge og Danmark nu nærmere på idealtypen end Sverige. Sådanne formelt udledte og fintkornede kvalitative og kvantitative differentieringer har hidtil ikke været muligt for case- og variabel-orienterede studier. Case-orienterede studier har vanskeligt ved formelt og kvantitativt at differentiere mellem cases inden for samme kategori, ligesom variabel-orienterede studier ikke tilgodeser det holistiske eller konfigurationelle syn bag idealtyper og dermed har problemer med kvalitativ differentiering ved et medium antal cases.

\section{Konklusion}

Vi har i det foregående set, hvordan studier af specifikke cases' konformitet med idealtyper går gennem fire stadier:

1. Informeret af teoretisk og substantiel viden identificerer forskeren idealtypernes aspekter (lig fuzzy mængder) og deres konfiguration. Dette leder til konstruktionen af et brugbart analytisk egenskabsrum, etablering af empiriske indikatorer for de valgte fuzzy mængder og procedurer for oversættelsen af rådata til fuzzy medlemsskabsværdier og verbale udsagn.

2. Specifikation af cases medlemskab af disse fuzzy mængder, dvs. medlemsskabsværdier der reflekterer i hvilket omfang cases er inde eller ude af en mængde, hvor 0 er fuldt ude, 1 er fuldt inde og 0,5 er krydspunktet mellem at være mere inde end ude.

3. Beregning af medlemskab for cases i den idealtypiske model, dvs. casen's placering i det analytiske egenskabsrum ved hjælp af principperne fra fuzzy mængdelære. 
4. Evaluering af homogenitet af cases på baggrund af informationen fra det forrige stadie.

Det skulle således fremgå, at fuzzy mængdelære giver en kalkulus for komparabilitet, der er særlig anvendelig i studiet af idealtyper. Da idealtyper forbinder samfundsvidenskabelig teori med en historisk forståelse, er de brugt flittigt i såvel klassisk som nutidig komparativ forskning. Fuzzy mængdelære giver formaliserede måle- og beregningsegenskaber i behandling af komplekse, teoretiske koncepter og analytiske konstruktioner. Det gør fuzzy mængdelære til et effektivt instrument $\mathrm{i}$ beskrivelsen af den komplekse, sociale verden. Fuzzy mængdelære giver præcision og raffinement til studiet af idealtyper.

I eksemplet omkring familiepolitiske modeller blev det vist, hvordan det var muligt at sammenligne nationale politikker og vurdere deres forandringer over tid. Hermed skulle det være demonstreret, hvordan fuzzy mængdelære har en række fordele sammenholdt med konventionelle variabel-orienterede og caseorienterede studier. For det første, at fuzzy mængdelære i sit krav til en eksplicit definition af det undersøgte fænomen, her familiepolitiske modeller, stimulerer udveksling af ideer og vidensakkumulation. For det andet, at et holistisk syn på cases bliver fremmet af at se aspekter som meningsfyldt fungerende i kombinationer, der ikke er til stede ved brug af konventionelle statistiske metoder med lille til medium N. Dette syn er endvidere som vist tro mod den weberianske konstruktion og forståelse af idealtyper. For det tredje, at fuzzy mængdelæres mulighed for at tillade delvist medlemskab af mængder gør det muligt at undersøge cases konformitet til koncepter og idealtyper. Dette gør det, for det fjerde, muligt at evaluere homogeniteten af cases. Især giver fuzzy mængdelære os nye muligheder for at studere diversitet, den samtidige forskel i type og grad, mellem lande og over tid. Derved giver fuzzy mængdelære os en ny metode til at studere weberianske idealtyper, og hvordan empiriske fænomener er ens og hvordan de afviger fra forud definerede analytiske konstruktioner. Hovedbidraget fra fuzzy mængdelære er derved, at den i et vist omfang bygger bro mellem case- og variabel-orienterede tilgange og i studiet af idealtyper giver os nye muligheder for at kombinere sociologisk teori med en historisk forståelse. Fuzzy mængdelære søger selvsagt ikke at afløse case- eller variabel-orienterede metoder, men det giver samfundsforskere en ny måde at arbejde videnskabeligt med konceptualisering, konfigurationer og kategorisering af cases. En ny måde at arbejde med begrebsliggørelse, teoretiske konstruktioner og studiet af den empiriske virkelighed.

\section{Noter}

1. Arbejdet bag denne artikel har modtaget støtte fra Statens Samfundsvidenskabelige Forskningsråd. Ole Gregersen, Erik Jørgen Hansen og Mads Jæger takkes for nyttige kommentarer på et tidligere artikeludkast.

2. Komparativ forskning kan forstås bredt som al forskning ud fra devisen at 'al tænkning indebærer sammenligning' eller snævert som tværnationale studier. I denne artikel bruger vi begrebet til at dække tid-rum sammenligninger, hvilket også var en yndet strategi hos de nævnte klassikere.

3. Da disse er udførligt beskrevet i talrige lærebøger, vil vi ikke komme nærmere ind på dem her (men se fx Ragin 1994, og Hansen og Andersen 2000, som også har en kritisk diskussion af sammenligneligheden af tværnationale data).

4. Da der endnu ikke er nogen alment accepteret dansk oversættelse af de oprindelige, engelske termer 'fuzzy set theory' og 'fuzzy sets' anvender vi gennemgående hhv. 'fuzzy mængdelære' og 'fuzzy mængder'. 
5. Til den socialdemokratiske familiepolitiske models særtræk kunne føjes omfattende orlovsordninger, ligesom der også kunne opsættes andre, og måske vigtigere, konstituerende særtræk end de her nævnte for den konservative og liberale model. Da formålet med denne artikel dog ikke er at bidrage til teoridannelse, men snarere til metodeudvikling, vil vi af pladsmæssige hensyn og pædagogiske årsager holde os til de tre nævnte aspekter.

6. Dette gælder den såkaldte pro-traditionelle variant af den konservative model, men ikke den pro-natale variant (for nærmere se Antonnen \& Sippilä 1996, Björnberg 1999, Rostgaard og Lehto 2000).

7. For en nærmere gennemgang se $\mathrm{fx}$ Weber (1904) eller Ringer (1997).

\section{Litteratur}

Abrahamson, Peter 1999: "The Welfare Modelling Business", Social Policy $\mathcal{E}$ Administration, 33(4): 394-415.

Antonnen, Anneli \& Jorma Sippilä 1996: "European Social Care Services: Is it possible to identify models?", Journal of European Social Policy, 6(2): 87-100. Björnberg, Ulla 1999: "Familiers pligter og ansvar: Skandinaviske familier i Europa", i: Lars Dencik og Per Schultz Jørgensen (red.), Børn og familie $i$ det postmoderne samfund. København: Hans Reitzels Forlag: 503-30.

Borchorst, Anette 1994: "Welfare State Regimes and Women's Interests, in Western Europe and the EC", i: Diane Sainsbury (red.), Gendering Welfare States. London: Sage: 26-45.

Brazelton, T.B. 1992: Touchpoints: Your Childs' Emotional and Behavioral Development. Reading, Massachusetts: Addison-Wesley.

CASA 1993: Forbrugerstyrelsens familiebudget, rapport 1993:2. København: Forbrugerstyrelsen.

Collin, Finn 1996: "Værdi og idealtype hos Max Weber", Dansk Sociologi, 7(4): 53-70.
Dogan, Mattei \& Ali Kazangil 1994: Comparing Nations: Concepts, Strategies, Substance. Oxford: Basil Blackwell.

Esping-Andersen, Gøsta 1990: The Three Worlds of Welfare Capitalism. Cambridge: Cambridge University Press.

Esping-Andersen, Gøsta 1999: Social Foundations of Postindustrial Economies. Oxford: Oxford University Press.

Goldthorpe, John 1997: "Current Issues in Comparative Macrosociology: A Debate on Methodological Issues", Comparative Social Research, 16: 1-26.

Goul Andersen, Jørgen 1996: "Velfærdssystem, marginalisering og medborgerskab", Dansk Sociologi, 7(1): 7-39.

Hansen, Erik Jørgen og Bjarne Hjorth Andersen 2000: Et sociologisk værktøj - om den kvantitative metode. København: Hans Reitzels Forlag.

Hansen, Finn Kenneth 1998: "Forbrugerstyrelsens Familiebudget 1998", Råd E Resultater, nr. 8: 13-20.

Hansen, Hans, div. år: Elements of Social Security. København: Socialforskningsinstituttet.

Hantrais, Linda \& Steen Mangen 1996: Cross-national Research Methods in the Social Sciences. London: Pinter.

Hatland, Aksel 2000: "Changing family patterns - A challenge to social security", i Mikko Kautto et al. (red.), op.cit.

Hobson, Barbara, Jane Lewis og Birthe Siim (red.) 2000: Key Concepts in Gender and the Welfare State. Aldershot: Edward Elgar. (under udgivelse)

Howes, C. 1997: “Children's Experiences in Center-Based Child Care as a Function of Teacher Background and Adult : Child Ratio", Merrill-Palmer Quarterly, 43(3): 404-25.

Janoski, Thomas \& Alexander Hicks (red.) 1994: The Comparative Political Economy of the Welfare State. Cambridge: Cambridge University Press. 
Kautto, Mikko, Johan Fritzell, Bjørn Hvinden, Jon Kvist og Hannu Uusitalo (red.) 2000: Nordic Welfare States in the European Context. London: Routledge. Under udgivelse.

Kaplan, Abraham \& Hermann Schott 1951: "A Calculus for Empirical Classes", Methodos, 3: 165-90.

King, Gary, Robert O. Keohane og Sidney Verba 1994: Designing Social Inquiry: Scientific Inference in Qualitative Research. Princeton, NJ: Princeton University Press.

Kjeldstad, Randi 2000: "Gender policies and gender equality", i; Mikko Kautto et al. (red.), op.cit.

Kvist, Jon 1999: "Welfare Reform in the Nordic Countries in the 1990s: Using Fuzzy Set Theory to Assess Conformity to Ideal Types", Journal of European Social Policy, 9(3): 231-52.

Lazarsfeld, Paul 1937: "Some remarks on Typological Procedures in Social Theory", Zeitschrift für Sozialforschung, 6: 119-39.

Leira, Arnlaug 1992: Welfare States and Working Mothers: The Scandinavian Experience. Cambridge: Cambridge University Press.

Lewis, Jane 1992: "Gender and the Development of Welfare Regimes", Journal of European Social Policy, 3: 159-73.

Lewis, Jane (red.) 1998: Lone Mothers and European Welfare Regimes. London: Jessica Kingsley.

Marshall, T.H. 1950: Class, Citizenship, and Social Development. New York: Doubleday.

Nososko (div. år): Social tryghed $i$ de nordiske lande. København: Nososko.

Orloff, Ann 1993: "Gender and the social rights of citizenship", American Sociological Review, 58: 303-28.

Peisner-Feinberg, E.S. \& M.R. Burchinal 1997: "Relations Between Preschool Children's Child-Care Experiences and Concurrent Development: The
Cost, Quality, and Outcomes Study", Merrill-Palmer Quarterly, 43(3): 45177.

Ragin, Charles 1994: Constructing Social Research. Thousand Oaks: Pine Forge Press.

Ragin, Charles 1997: "Turning the Tables: How Case-Oriented Research Challenges Variable-Oriented Research", Comparative Social Research, 16: 27-42.

Ragin, Charles 2000: Fuzzy-Set Social Science. Chicago: Chicago University Press.

Ringer, Fritz 1997: Max Weber's Methodology: The Unification of the Cultural and Social Sciences. Cambridge, Massachusetts: Harvard University Press.

Rostgaard, Tine \& Juhani Lehto 2000: "Health and social care systems: How different is the Nordic model?", i: Mikko Kautto et al. (red.), op.cit.

Scarpetta, Stefano 1996: "Assessing the Role of Labour Market Policies and Institutional Settings on Unemployment: A Cross-Country Study", OECD Economic Studies, 26: 43-98.

Shalev, Michael 1998. "Limits of and Alternatives to Multiple Regression in Macro-Comparative Research"', paper presented at the second conference on The Welfare State at the Crossroads, Stockholm, June 12-14.

Siim, Birte 1999: Politics Matters - Gender and Citizenship in France, Britain and Denmark. Cambridge: Cambridge University Press.

Sippilä, Jorma (red.) 1997: Social Care Services: The Key to the Scandinavian Model. Aldershot: Avebury.

Smithson, Michael 1988: "Fuzzy Set Theory and the Social Sciences", Fuzzy Sets and Systems, 26:1-21.

Sørensen, Annemette 2000: "Gender equality in earnings at work and at home", i: Mikko Kautto et al. (red.), op.cit. 
Weber, Max [1904] 1949: "'Objectivity' in Social Science and Social Policy", i: Max Weber, The Methodology of the Social Sciences. Glencoe, Illinois: The Free Press: 49-112.
Yin, Robert K. 1994: Case Study Research - Design and Methods, $2^{\text {nd }}$ edition. London: Sage.

Zadeh, Lotfi 1965: 'Fuzzy Sets', Information Control, 8: 338-53. 